\begin{tabular}{|l|l|l||}
\hline \multicolumn{2}{|c|}{ PublisherInfo } \\
\hline \hline PublisherName & $:$ & BioMed Central \\
\hline \hline PublisherLocation & $:$ & London \\
\hline \hline PublisherImprintName & $:$ & BioMed Central \\
\hline \hline
\end{tabular}

A link between $W N T 2$ and increased susceptibility to autism?

\begin{tabular}{||l|l|l||}
\hline \multicolumn{2}{|c||}{ ArticleInfo } \\
\hline \hline ArticleID & $:$ & 4096 \\
\hline \hline ArticleDOI & $:$ & $10.1186 /$ gb-spotlight-20010524-02 \\
\hline \hline ArticleCitationID & $:$ & spotlight-20010524-02 \\
\hline \hline ArticleSequenceNumber & $:$ & 167 \\
\hline \hline ArticleCategory & $:$ & Research news \\
\hline \hline ArticleFirstPage & $:$ & 1 \\
\hline \hline ArticleLastPage & $:$ & 2 \\
\hline \hline & $:$ & RegistrationDate : 2001-05-24 \\
ArticleHistory & $:$ & OnlineDate \\
\hline \hline ArticleCopyright & $:$ & BioMed Central Ltd2001-05-24 \\
\hline \hline ArticleGrants & $:$ & \\
\hline \hline ArticleContext & $:$ & 130592211 \\
\hline \hline
\end{tabular}




\section{SPIS MedWire}

Email: medwire@sciencenow.com

In the June American Journal of Medical Genetics, Thomas Wassnik and colleagues from the Universities of Iowa and North Carolina report on the identification of rare mutations in the gene WNT2 that may "significantly increase susceptibility to autism," as well as a common variant that may contribute to the disorder to a lesser degree. "While the evidence implicating this gene is good, it's not over-whelming, and must be replicated by other groups," caution the authors.

Wassink et al. examined $W N T 2$ as a candidate disease gene for autism because it is located on a region of chromosome 7, that has previously been linked to autism. In addition, animal studies in which the gene had been knocked out resulted in animals exhibiting behavioural phenotypes similar to autism in humans.

The authors screened 135 unrelated autistic individuals and compared the WNT2 sequences with those from 160 individuals who did not have autism. They found two families in which mutated variants of the WNT2 gene were expressed in one parent and only in those children who developed autism, but not in any of the healthy siblings. No mutated versions of the WNT2 were found in the 160 controls.

In addition, the researchers identified linkage disequilibrium between a $W N T 2$ single-nucleotide polymorphism (SNP) and their sample of autism-affected sibling pair families. According to a previously published genome-wide linkage screen, this SNP was also found to be associated with linkage to 7q. Evidence for this association was found particularly among families with severe language impairments. The team points out that it is possible that the SNP - or an as-yet undiscovered nearby polymorphism - could confer susceptibility to autism by influencing expression of WNT2.

Wassink et al. are now working on the frizzled gene, which encodes a receptor for the secreted WNT proteins. They are also looking for mutations in other genes in WNT pathways that could be involved in the development of autism.

\section{References}

1. Wassink TH, Piven J, Vieland VJ, Huang J, Swiderski RE, Pietila J, Braun T, Beck G, Folstein SE, Haines JL, et al: Evidence supporting WNT2 as an autism susceptibility gene. Am J Med Genet 2001, 101., [http://www3.interscience.wiley.com/cgi-bin/abstract/81502711/START]

2. University of Iowa, [http://www.uiowa.edu/]

3. University of North Carolina, [http://www.northcarolina.edu/]

4. A full genome screen for autism with evidence for linkage to a region on chromosome 7q. International Molecular Genetic Study of Autism Consortium. 